\title{
Zmiany w polityce antyrasistowskiej Unii Europejskiej w latach 2000-2020
}

\begin{abstract}
I. Wstęp
Problem rasizmu jest dyskutowany w Unii Europejskiej (UE) od połowy lat 80. ubiegłego wieku. Pojawiające się w latach 90. ubiegłego wieku dokumenty dotyczące walki z rasizmem odwoływały się do art. K.1 ust. 7 Traktatu o UE, czyli możliwości współpracy sądowej państw członkowskich w sprawach karnych. Jednak przez kilkanaście lat żaden znaczący postęp w zakresie walki z rasizmem nie został uczyniony, ponieważ podjęcie działań w tym kierunku spotykało się z opozycją w Radzie UE. Sytuacja zmieniła się wraz z wprowadzeniem w 1997 r. przez traktat amsterdamski (TA) artykułu stanowiącego, iż UE będzie zwalczać dyskryminację ze względu na pochodzenie rasowe i etniczne oraz wraz z przyjęciem w 2000 r. dyrektywy 2000/43/ WE (tzw. Dyrektywy Rasowej) wprowadzającej w życie zasadę równego traktowania bez względu na pochodzenie rasowe i etniczne. W motywie 7 preambuły tej dyrektywy stwierdza się, że wprowadzone przez TA przepisy odnośnie do dyskryminacji ze względu na pochodzenie rasowe mają posłużyć do walki z rasizmem (CEU, 2000). Od tego czasu UE podjęła szereg działań zmierzających w ściśle określonym celu (tj. wyeliminowania rasizmu), w związku z czym można powiedzieć, że prowadzi ona politykę antyrasistowską. Przez cały ten okres zjawisko rasizmu było w Europie obecne, a w ostatnich kilku latach nawet się nasiliło. Interesujące jest nie tylko to, w jaki sposób dzisiaj UE stawia czoła rasizmowi, ale też, jaka sekwencja zmian doprowadziła do obecnego kształtu polityki antyrasistowskiej UE. Celem niniejszego artykułu jest zatem pokazanie, na czym polegały zmiany w polityce antyrasistowskiej UE i jaki charakter miały one same oraz ich sekwencja. Cel ten został zrealizowany poprzez odpowiedź na pytanie o zmiany w zakresie: konceptualizacji problemu polityki antyrasistowskiej UE, jej celów, środków oraz sposobów jej organizacji. Badania objęły okres od momentu przyjęcia Dyrektywy Rasowej aż do końca 2020 roku.
\end{abstract}

\section{Teoria i metoda}

Do analizy zmian polityki antyrasistowskiej UE wykorzystano teorię konstruktywistycznego instytucjonalizmu, która instytucjonalną dynamikę postrzega nie tylko jako zależność od wcześniejszych decyzji twórców instytucji (tzw. zależność od ścieżki), ale ponadto pokazuje, że ograniczenia na polityczną autonomię nakładają idee, 
które mają wpływ na kształt oraz rozwój instytucji. Wykorzystana została również teoria paradygmatu polityki publicznej (policy paradigm), która pokazuje, że zmiana polityki może następować niezależnie w dwóch obszarach: kognitywno-normatywnym kompleksie problemów i rozwiązań oraz w kompleksie strukturalno-organizacyjnym danej polityki. Zmiany w zakresie pierwszego z wymienionych kompleksów obejmują konceptualizację problemu, który wymaga publicznej interwencji, sposobu rozwiązania problemu (środków) oraz celów polityki. Zmiany w ramach drugiego kompleksu dotyczą władz, ekspertów (źródeł wiedzy) oraz sposobu tworzenia polityki (Carson, Burns, Calvo, 2009, s. 150).

Do analizy zmian w pierwszym z wymienionych kompleksów materiał badawczy stanowiły 62 dokumenty w języku angielskim (rozporządzenia, dyrektywy, decyzje, rezolucje, deklaracje, konkluzje, rekomendacje, plany działania) przyjęte przez główne instytucje UE biorące udział w procesie legislacyjnym: Komisję Europejską (KE), Radę UE (RUE) oraz Parlament Europejski (PE). Warto podkreślić, że badanie dotyczyło polityki (policy), a nie jedynie wiążącego prawa. Na politykę składają się prócz wiążących aktów prawnych również dokumenty typu plany działania, rekomendacje, konkluzje itd., stąd badaniem objęto dokumenty różnej rangi. Dokumenty zostały wyselekcjonowane w ten sposób, że do wyszukiwarek w archiwach znajdujących się na oficjalnych stronach tych instytucji zostało wpisane słowo kluczowe racism. Dokumenty potraktowano jako część dyskursu koordynacyjnego między wspomnianymi instytucjami, dlatego $\mathrm{w}$ ich badaniu zastosowano odmiany analizy dyskursu zwane ilościową i jakościową analizą zawartości. Wcześniej na podstawie teorii paradygmatu polityki publicznej określono strukturę kodów (kategorii analitycznych), a następnie dokumenty zostały zakodowane z wykorzystaniem oprogramowania QDA Miner 9, zaś do określenia częstotliwości występowania słów i kodów wykorzystano program WordStat 9. Do analizy zmian w kompleksie strukturalno-organizacyjnym wykorzystano dokumenty KE, PE oraz literaturę przedmiotu.

\section{Analiza zmian}

\section{Zmiany w zakresie konceptualizacji problemu}

Nikogo nie zdziwi stwierdzenie, że w analizowanym materiale jako pierwszorzędny problem domagający się publicznej interwencji wskazywany jest fenomen rasizmu. Już w dokumentach pochodzących z początku badanego okresu można znaleźć stwierdzenie, że rasizm należy zwalczać (EP, 2000) ${ }^{1}$. Przy czym do chwili obecnej żadna $\mathrm{z}$ głównych instytucji UE nie podjęła próby zdefiniowania rasizmu czy pochodzenia rasowego. Jednakże analiza dokumentów UE pokazuje, że możliwe jest zrekonstruowanie sposobu, w jaki ich autorzy pojmują rasizm. Z treści tych dokumentów

${ }^{1}$ W przypisach do dokumentów UE będzie umieszczony skrót nazwy instytucji UE w języku angielskim. Nie wszystkie wykorzystane dokumenty posiadają wersję w języku polskim, stąd analizy oparto na wersjach w języku angielskim (EC - European Commission, CEU - Council of the European Union, EP - European Parliament). 
można wywnioskować, że rasizm jest rozumiany na trzy sposoby, a mianowicie jako rasizm naukowy, kulturowy i instytucjonalny. Pierwsza z koncepcji oznacza przekonanie o wyższości jednych ras czy grup nad innymi, druga - nieakceptację samego faktu istnienia różnorodności etnicznej, kulturowej, językowej itp., natomiast trzecia - nie zwraca uwagi na indywidualne postawy i intencjonalne działania, ale wskazuje rolę codziennych i rutynowych praktyk, które skutkują faworyzowaniem jednych grup, a niekorzystnym traktowaniem innych (Bell, 2008, s. 9-11). Wszystkie trzy koncepcje można odnaleźć $\mathrm{w}$ analizowanym materiale na przestrzeni całego badanego okresu. Przy czym idea rasizmu naukowego, choć obecna już na początku (EP, 2000; EP, 2001a), to jednak po 2015 r. występuje zdecydowanie częściej (EP, 2015a; EP, 2017b; EP, 2018a; EP, 2019b; EC, 2020c). Odwołań do koncepcji kulturowej można dopatrzeć się w tych miejscach, w których jest mowa o rasizmie dotykającym grupy etniczne, językowe i religijne oraz we fragmentach zawierających wezwanie do umocnienia różnorodności. Nigdzie jednak nie ma wyraźnie wyartykułowanego przekonania, że rasizm rodzi się z faktu nieakceptacji różnorodności, co stanowi główne założenie koncepcji rasizmu kulturowego. Tylko niekiedy można znaleźć stwierdzenia o napięciach z powodu współistnienia kultur (EP, 2004; EP, 2006b). Od samego początku badanego okresu spoza fragmentów wielu tekstów prawnych opublikowanych na przestrzeni całego okresu objętego analizą w dokumentach UE obecne jest pojęcie rasizmu instytucjonalnego oraz bardzo bliskie mu pojęcie rasizmu strukturalnego. Wraz z upływem lat, a zwłaszcza od 2015 r., idee te są coraz częściej przywoływane przez unijnych decydentów (np. EP, 2017b; EC, 2020a). Warto zaznaczyć, że posługiwanie się ideą rasizmu nie oznacza, że UE akceptuje tę wizję rzeczywistości. W dwóch dokumentach można znaleźć stwierdzenie, że UE odrzuca wszystkie teorie mówiące o istnieniu odrębnych ras ludzkich (CEU, 2000; EP, 2001a).

W dokumentach UE pokazywane są zarówno bardzo wyraziste, jak i niemal niewidoczne przejawy rasizmu. Tych pierwszych jest zdecydowanie więcej. Należą do nich: dyskryminacja ze względu na pochodzenie rasowe (bezpośrednia, pośrednia, molestowanie, polecenie dyskryminacji) (CEU, 2000), profilowanie rasowe (EC, 2020a), rasistowska retoryka (EP, 2010b), nawoływanie do przemocy lub nienawiści, zaprzeczanie ludobójstwu i zbrodniom wojennym skierowanym przeciwko grupom definiowanym na podstawie kryteriów rasowych i im podobnych, jeśli czyny takie mogą podburzać do przemocy lub wzbudzać nienawiść przeciw tym grupom lub ich członkom (CEU, 2008), mowa nienawiści (EP, 2015b), nienawiść rasowa (CEU, 2008), nękanie (EC, 2020a), akty przemocy (EC, 2001), fizyczne ataki (EP, 2005b), zbrodnie z nienawiści (w tym niewolnictwo i czystki etniczne) (CEU, 2001a). Do mniej wyrazistych przejawów rasizmu zaliczone zostały niezbyt widoczne praktyki dyskryminacyjne, które stają się codziennością dla osób ich doświadczających (EC, 2003). W zakresie prezentowania przejawów rasizmu można zaobserwować zmianę polegająca na tym, że od 2013 r. jako przejaw rasizmu coraz częściej wymienia się zbrodnie z nienawiści (hate crimes), od 2014 r. mowę nienawiści (hate speech).

Niezmiennie przez cały badany okres pokazuje się, że rasizm nie jest marginalnym problemem, bowiem dotyczy wielu ważnych dla obywateli obszarów życia: szkoleń zawodowych (EP, 2004), zatrudnienia, pracy, edukacji, zabezpieczeń społecznych, dostępu do dóbr i usług (EC, 2003), mieszkalnictwa (EP, 2010b), opieki zdrowotnej (EP, 2005b), 
sportu (EC, 2001), finansów (EC, 2020a). Niezmiennie też kierowana jest uwaga na media, a zwłaszcza internet jako na przestrzeń, która umożliwia propagowanie rasizmu (CEU, 2001a). W 2020 r. pojawia się idea rasizmu środowiskowego (environmental racism), która oznacza sytuację narażenia grup marginalizowanych i mniejszościowych na nieproporcjonalne zagrożenia środowiskowe, odmowę dostępu do ekologicznych źródeł utrzymania takich jak czyste powietrze, woda i zasoby naturalne, a także naruszenie praw człowieka związanych ze środowiskiem. Pojęcie rasizmu środowiskowego w dokumentach UE zostało odniesione do sytuacji Romów (EC, 2020b).

Autorzy badanych dokumentów UE, chcąc pokazać, że rasizm rzeczywiście stanowi problem wymagający publicznej interwencji pokazują jego negatywne konsekwencje dla jednostek i społeczności. Spośród szkód, jakie powoduje rasizm w życiu jednostek niezmiennie wskazywane są: brak pracy (EP, 2017b), niewystarczający dostęp do zatrudnienia, dóbr i usług, opieki medycznej (CEU, 2001a), złe warunki socjalno-ekonomiczne, w tym problemy mieszkaniowe (EP, 2020b), ubóstwo, wykluczenie społeczne (EP, 2004), marginalizacja (EP, 2017), przymusowa sterylizacja kobiet romskich (EP, 2004), stygmatyzacja (EP, 2015b), wiktymizacja (EC, 2006). Za negatywny skutek rasizmu dla społeczeństw zostały uznane: nierówności społeczne (CEU, 2001b), segregacja społeczna (EP, 2005b) oraz słabnięcie rządów prawa i demokracji (EP, 2005a). Powyższe negatywne konsekwencje rasizmu, zarówno w wymiarze jednostkowym, jak społecznym, w dyskursie unijnym zostały przedstawione przy użyciu dwóch ram konceptualnych: socjalno-ekonomicznej i aksjologicznej. Ta pierwsza eksponuje konsekwencje o charakterze bytowym (np. gorsze warunki życia) i społecznym (np. nierówności, gorsze funkcjonowanie demokracji), a więc ramuje problem jako uszczerbek o charakterze socjalno-ekonomicznym. Ta druga ma na celu wydobyć zagrożenie dla wartości i zasad, zwłaszcza unijnych. Ramuje problem jako uszczerbek w zakresie możliwości urzeczywistnienia wartości i zasad (podważenie wartości osoby, dehumanizacja, naruszenie praw podstawowych, zasady rządów prawa i demokracji) (EC, 2014a). Obydwie ramy współistnieją, nie można wskazać dominacji żadnej z nich, trudno też uchwycić zmianę w tym zakresie.

Konceptualizacja problemu, jaki stanowi rasizm, obejmuje również jego ofiary. Pojęciem tym określane są mniejszości bądź osoby należące do mniejszości, a jeszcze częściej członkowie grup definiowanych na podstawie koloru skóry, rasy, religii, pochodzenia narodowego czy etnicznego (EC, 2002). W ciągu całego badanego okresu bardzo często wymienianą grupą, której członkowie stają się ofiarami rasizmu są Romowie (niekiedy też Sinti), w tym romskie kobiety i dzieci (EP, 2004). Ponadto do ofiar rasizmu zaliczono migrantów i ich potomków, uchodźców i ich dzieci (EP, 2019a), azylantów (EP, 2001b), kobiety migrantki (EP, 2004), ludność autochtoniczną (indigenous people) (EC, 2001), Żydów, muzułmanów, w tym kobiety muzułmanki (EP, 2005a) i ludzi o arabskim pochodzeniu (EC, 2003). Od 2015 r. w dokumentach UE jako ofiary rasizmu zaczynają być wymieniani ludzie o pochodzeniu afrykańskim (people of African descent) (EC, 2019), a od 2018 r. osoby czarnoskóre (Black people). O ile częstotliwość wymieniania tych pierwszych w 2020 r. słabnie, to ci drudzy po 2018 r. niezmiennie pojawiają się w oficjalnym dyskursie instytucji UE. W badanych dokumentach można odnaleźć liczne neologizmy: Romaphobia, anti-Gypsyism, Afrophobia, Afriphobia, anti-Black racism, anti-Asian racism (EP, 2015a; EC, 2020d). Po- 
kazują one, że w odniesieniu do określonych grup mamy do czynienia ze szczególnym rodzajem rasizmu, który wymaga nowej nazwy, zaś zaliczenie niektórych z nich do kategorii fobii, jak wydaje się, ma na celu wyostrzenie problemu. W dokumentach UE neologizmy te funkcjonują obok takich określeń jak nienawiść wobec muzułmanów (anti-Muslim hatred) oraz już wcześniej upowszechnionego pojęcia antysemityzmu i islamofobii. Podkreśla się również, że postawa rasizmu często łączy się z dyskryminacją i nienawiścią ze względu na inne kryteria, np. płeć, religię, język, orientację seksualną, wiek, niepełnosprawność (EP, 2019a). Choć stwierdzenie dotyczące uwarunkowania jednej postawy różnymi czynnikami jest obecne przez cały badany okres, to warto zauważyć, że pojęcie intersectional discrimination (dyskryminacja międzysegmentowa/krzyżowa/zbieżna) w latach 2015-2019 r. pojawia się o wiele częściej. Pojęcie to wskazuje na dyskryminację, która opiera się na kilku kryteriach, pomiędzy którymi zachodzą określone relacje, tak że nie można ich oddzielić, a rozmiar odczuwanej przez osobę opresji pochodzi z synergicznego działania tych wielu kryteriów na jedną osobę, w jednym punkcie, w jednym czasie.

Jako przyczynę problemu rasizmu decydenci UE wskazali działania jednostek, grup oraz przyczyny strukturalne. W jednym z dokumentów stwierdzono, że dyskryminacja wynika głównie z ignorancji (rodzącej strach) co do innych ludzi (EP, 2006a). Decydenci UE w roli ,złego”, który odpowiedzialny jest za podsycanie rasizmu, obsadzili liderów opinii, polityków, partie polityczne, ruchy polityczne i grupy paramilitarne, którzy opierają swoją ideologię, dyskurs oraz praktyki na rasizmie. Niektóre spośród tych partii, ruchów i grup nazywano ekstremistycznymi. Pokazano, że inkorporowały one elementy neofaszystowskie bądź są w zmowie z neofaszystami i neonazistami (EP, 2018b). Działanie tych podmiotów polega na podsycaniu strachu, wykorzystywaniu kryzysu ekonomicznego i społecznego do wskazania społeczeństwu kozła ofiarnego (EP, 2007b; EP, 2012). Uprzedzenia w stosunku do określonych grup podmioty te wykorzystują w celach politycznych (EP, 2001a). Częstą praktyką jest też normalizacja rasizmu (EP, 2018b). Bardzo rzadko jako sprawcy aktów rasistowskich wskazywani są w dokumentach UE policjanci (EP, 2005c) oraz instytucje odpowiedzialne za egzekwowanie prawa. Pokazuje się, że również one bywają w zmowie z grupami neofaszystowskimi i neonazistowskimi (EP, 2018a). Jeden raz zostały wymienione państwa członkowskie UE, które promują bądź przyzwalają na zinstytucjonalizowaną dyskryminację rasową (EP, 2017b).

Drugi rodzaj przyczyn problemu rasizmu stanowią czynniki strukturalne. Po pierwsze, autorzy dokumentów UE przekonują, że rasizm jest głęboko zakorzeniony w strukturze społecznej, ponieważ ma swoje korzenie w historii, tzn. ukształtował się w kontekście kolonializmu, niewolnictwa i holokaustu (EC, 2020a). Za sprawą tych historycznych wydarzeń żywe jest dzisiaj określone postrzeganie ,inności”, funkcjonują uprzedzenia i negatywne stereotypy. Źródło strukturalnej dyskryminacji stanowi też ukształtowana w określony sposób legislacja, praktyka jej stosowania oraz sposób prowadzenia polityki (EC, 2020a).

Nową ideę, która pojawiła się w 2020 r., stanowi przekonanie, iż nowe technologie, zwłaszcza wykorzystanie algorytmów zwane sztuczną inteligencją, może podtrzymywać, a nawet stymulować rasowe uprzedzenia, jeśli wykorzystywane przez nie dane nie będą odzwierciedlać różnorodności społeczeństw UE (EC, 2020a). 
Jeśli chodzi o dynamikę w odniesieniu do przyczyn problemu rasizmu, to nie można jednoznacznie stwierdzić, że jedna grupa czynników przeważa nad innymi w danym okresie. Przez cały badany okres obydwa rodzaje wyjaśnień współistnieją. Ta tendencja stanowi potwierdzenie obecności w dokumentach UE różnych koncepcji rasizmu, bowiem koncepcja rasizmu naukowego wskazuje na przyczyny o charakterze intencjonalnym, zaś koncepcja rasizmu instytucjonalnego/strukturalnego na czynniki nieintencjonalne (instytucjonalne, strukturalne).

\section{Zmiany w zakresie środków}

W celu rozwiązania problemu rasizmu, skonceptualizowanego jak to przedstawiono powyżej, decydenci UE zaordynowali cztery rodzaje środków: przymusu i ochrony prawnej, kształtujące świadomość i postawy, poprawiające sytuację grup zagrożonych rasizmem, pomagające w tworzeniu efektywnej polityki antyrasistowskiej. Do pierwszej grupy należy zaliczyć instrumenty prawne (np. zakazujące dyskryminacji ze względu na pochodzenie rasowe i etniczne), których celem jest zniechęcenie do zachowań o charakterze rasistowskim za sprawą przewidzianych w tych przepisach sankcji. W dokumentach UE znajdujemy stwierdzenie, że za akty rasistowskie należy karać skutecznie (EP, 2000). Instrumenty prawne mają też zapewnić ofiarom ochronę przed niekorzystnymi działaniami (np. zwolnieniem z pracy) oraz możliwość dochodzenia roszczeń przed sądem. Istnieje też ustawodawstwo zabraniające dyskryminacji rasowej o charakterze pośrednim, czyli wprowadzania pozornie neutralnych przepisów, które skutkują tym, że określona grupa znajduje się w niekorzystnej sytuacji w porównaniu do innych grup. Zmianę w zakresie stosowania instrumentów prawnych można zaobserwować w związku z przyjęciem przez Radę UE w 2008 r. Ramowej Decyzji 2008/913/WSiSW. Nowość tego aktu prawnego polega na tym, że częściowo harmonizuje on istniejące $w$ państwach członkowskich różne sposoby zwalczania rasizmu, wskazując te jego formy, które powinny być zwalczane poprzez środki prawnokarne. Do szczególnie poważnych form rasizmu, które powinny być uwzględnione w prawie karnym zostało zaliczone publiczne nawoływanie do przemocy lub nienawiści wobec określonych grup (w tym za pomocą rozpowszechniania tekstów, obrazów i innych materiałów) oraz publiczne aprobowanie, negowanie lub rażące pomniejszanie zbrodni ludobójstwa, zbrodni przeciwko ludzkości oraz zbrodni wojennych skierowanych przeciwko grupom definiowanym przez kryteria rasowe i im podobne, jeśli czyny takie mogą podburzać do przemocy lub wzbudzać nienawiść przeciwko tym grupom lub ich członkom. Nowość omawianej tu decyzji ramowej polega również na tym, że za wspomniane czyny przewiduje sankcje nie tylko dla osób fizycznych, ale także osób prawnych (CEU, 2008). W zakresie środków prawnych uwagę zwraca przywiązywanie dużej wagi do ochrony i wspomagania ofiar aktów dokonanych z pobudek rasistowskich. Na początku badanego okresu wprowadzono przepisy ustanawiające tzw. przeniesiony ciężar dowodu. Dzięki nim w sprawach sądowych o dyskryminację rasową i etniczną ofiary nie muszą udowodnić dyskryminacji, ale to strona pozwana jest zobowiązana wykazać, iż działania, których dyskryminacyjny charakter zarzuca powód, były uzasadnione obiektywnymi powodami albo nie nosiły znamion dyskryminacji (dy- 
rektywa 2000/43/WE). Ponadto, przepisy UE zobowiązują państwa członkowskie do powołania wyspecjalizowanych ciał, które będą zajmować się m.in. wspieraniem ofiar rasizmu w prowadzeniu ich sprawy w przypadku, gdy złożą skargę na dyskryminację rasową (CEU, 2000). Wzmocnienie ochrony i wsparcia ofiar przestępstw z pobudek rasistowskich nastąpiło w 2012 r. wraz z przyjęciem dyrektywy 2012/29/UE. Nakazuje ona traktować ofiary z szacunkiem, taktownie, profesjonalnie, bez dyskryminacji, zobowiązuje państwa członkowskie do indywidualnej oceny potrzeb ofiar oraz nakłada obowiązek zapewnienia uzupełniających (w stosunku do dyrektywy) środków ochrony. Analizowane dokumenty UE mówią o potrzebie wdrożenia programów szkoleniowych dla policji, przedstawicieli sądownictwa i osób świadczących usługi, których odbiorami są imigranci i członkowie mniejszości etnicznych w celu zaznajomienia ze specyfiką zjawiska rasizmu, przepisami antyrasistowskimi i sposobami zwalczania rasizmu (EP, 2000) oraz o konieczności międzypaństwowej współpracy policyjnej i sądowej w zakresie zwalczania przestępstw z pobudek rasistowskich (EC, 2001). Analiza dokumentów UE pokazuje, że ich twórcy, nie negując konieczności zastosowania jeszcze innych instrumentów, postrzegają prawo jako najważniejszy środek pozwalający zwalczyć rasizm (EC, 2020a). Środki prawne mają zaradzić przede wszystkim tym odmianom rasizmu, które przejawiają się w aktach intencjonalnych jednostek. Jedynie przepisy zabraniające dyskryminacji pośredniej dotyczą aktów nieintencjonalnych.

Drugi rodzaj środków stanowią działania kształtujące świadomość i postawy. W odniesieniu do nich nie zaobserwowano zmiany w badanym okresie. Decydenci UE niezmiennie zalecają wprowadzenie do programów szkolnych i przygotowania zawodowego nauczycieli nauczania o niebezpieczeństwie rasizmu w oparciu o historyczne fakty (kolonializm, holokaust) (EP, 2000). Edukacja powinna promować kulturę niedyskryminacji (EP, 2006b), szacunku i tolerancji (EP, 2013a), uczyć o wartości różnorodności (EP, 2000), zaznajamiać z obcymi kulturami i ich pozytywnym wkładem w europejską ekonomię i kulturę (CEU, 2000), promować wzajemne/międzykulturowe zrozumienie (EP, 2019d), dialog międzykulturowy (EP, 2004), pokój, niestosowanie przemocy, uczyć fundamentalnych wartości i zasad oraz szacunku do nich (EP, 2007c). Promocja prawa człowieka powinna stanowić także komponent polityki zewnętrznej UE (EC, 2001). Szkoły powinny zapobiegać radykalizacji, pomagać w promowaniu integracji ze społeczeństwem, rozwijać krytyczne myślenie, uczyć odpowiedzialnego, krytycznego, zgodnego z prawem korzystania z internetu (EP, 2015c). Wszyscy obywatele powinni zostać poinformowani o przepisach prawa antydyskryminacyjnego, z których mogą korzystać (EP, 2005b). W ramach kształtowania świadomości zaleca się, by przedstawiciele władz, partii politycznych i społeczeństwa obywatelskiego publicznie potępili rasizm (EC, 2014a). Ważne dla zrozumienia niebezpieczeństwa rasizmu jest upamiętnianie wydarzeń, które stanowią lekcję w tym zakresie (EC, 2020a). Należałoby też zadbać, by media nie zawierały treści nakłaniających do rasizmu (EC, 2020c). Powyżej zaprezentowane środki, oddziałujące na postawy i świadomość, są skierowane przeciwko zarówno intencjonalnym, jak i nieintencjonalnym przejawom rasizmu. Postulat ich zastosowania jest obecny w całym badanym okresie.

Trzeci rodzaj środków stanowią działania mające na celu zniwelowanie skutków rasizmu oraz zwiększenie zdolności grup zagrożonych rasizmem do przeciwstawienia 
się jemu. Zdaniem decydentów UE państwa członkowskie powinny prowadzić politykę, której efektem będzie polepszenie (w sensie substancjalnym) sytuacji grup dyskryminowanych i dotkniętych rasizmem w obszarze edukacji, mieszkalnictwa, zdrowia, zatrudnienia, usług społecznych, systemu sprawiedliwości, politycznej partycypacji i reprezentacji (EC, 2020c). Powinny zwalczać ekonomiczne, społeczne, polityczne i kulturowe wykluczenie zagrożonych rasizmem (CEU, 2000) oraz sprzyjać integracji migrantów ze społeczeństwem (EC, 2001). W ramach walki z dyskryminacją rasową dopuszcza się, tzw. środki pozytywne, które mają za zadanie grupom zagrożonym rasizmem zapewnić równość szans w praktyce. Mogą one obejmować na przykład priorytetowy dostęp do pewnych szkoleń zawodowych, gwarancje odbycia rozmowy kwalifikacyjnej o pracę, zapewnienie, by określone grupy rasowe i etniczne były w pełni poinformowane o ogłoszeniach o pracę, wyjątkowo mogą to też być systemy kwotowe. Środki pozytywne powinny być skierowane w stosunku do grup, które doświadczają długotrwałej niekorzystnej sytuacji związanej z pochodzeniem rasowym, której nie jest w stanie zaradzić podstawowe prawo antydyskryminacyjne. W dokumentach UE przestawia się je nie tylko jako uzupełnienie podstawowych środków prawnych, ale też jako sposób na zrekompensowanie wcześniejszej niesprawiedliwości (EP, 2006b). Środki należące do trzeciej kategorii mają na celu zwalczenie głównie rasizmu instytucjonalnego/strukturalnego oraz jego skutków. Można zaobserwować zwiększenie nacisku na zastosowanie tych środków po 2004 r. wraz z pojawieniem się „kwestii romskiej” na agendzie UE.

Czwartą grupę stanowią środki pomagające tworzyć efektywną politykę antyrasistowską. Do tej kategorii zalicza się przede wszystkim dane statystyczne. Państwa członkowskie są zobowiązane do monitorowania sytuacji i zbierania danych o dyskryminacji rasowej oraz innych aktach rasistowskich, wymieniania się między sobą tymi informacjami, a także dobrymi praktykami w zakresie radzenia sobie z rasizmem. Dane statystyczne potrzebne są do identyfikowania korzeni rasizmu, wykazania dyskryminacji pośredniej, ewaluacji polityk oraz tworzenia polityki antyrasistowskiej opartej na dowodach, co w konsekwencji pozwoli efektywnie zwalczyć rasizm (EC, 2001; EP, 2006a; EP, 2019b). Ponadto, rekomenduje się stosowanie przez państwa członkowskie strategii mainstreaming, polegającej na tym, że podczas procesu tworzenia różnych polityk w ich konstrukcji i implementacji uwzględnia się kwestię romską (mainstreaming of Roma issues) (EP, 2010b), walkę z antysemityzmem (mainstreaming the fight against antisemitism) (CEU, 2020) czy ogólniej rzecz ujmując walkę $\mathrm{z}$ rasizmem (mainstreaming the fight against racism) (EC, 2001). Strategia mainstreaming ma uzupełniać politykę ukierunkowaną na szczegółowe cele. Zaleca się też, aby podczas procesu formułowania polityki antyrasistowskiej włączać perspektywę genderową (tzw. gender mainstreaming), jako że dyskryminacja rasowa i rasizm bardzo często łączą się z dyskryminacją ze względu na płeć (CEU, 2001b). Rasizm stanowi zagrożenie zwłaszcza dla kobiet, które $\mathrm{z}$ tego powodu nie mogą w pełni korzystać z podstawowych praw i wolności (CEU, 2001a). Środki należące do czwartej kategorii mają zwalczyć przede wszystkim rasizm instytucjonalny/strukturalny. Wymieniane są w dokumentach UE przez cały badany okres.

Za wdrożenie wyżej wymienionych środków odpowiedzialne są przede wszystkim państwa członkowskie, a także, w zakresie swoich kompetencji, UE. Znaczącą 
rolę do odegrania mają też wyspecjalizowane ciała powołane przez państwa. Ponadto, państwom zaleca się, aby prowadziły działania ukierunkowane na zwalczenie rasizmu we współpracy z NGOs, partnerami społecznymi i innymi podmiotami ze sfery społeczeństwa obywatelskiego.

\section{Zmiany w zakresie celów polityki}

Zastosowanie wymienionych wyżej środków ma w zamierzeniu twórców antyrasistowskiej polityki UE doprowadzić do realizacji celów, które można podzielić na pośrednie i nadrzędne. Cele pośrednie są mierzalne, cele nadrzędne wskazują na wizję pożądanej sytuacji, której raczej nie sposób określić za pomocą mierzalnych wskaźników. Do celów pośrednich twórcy polityki antyrasistowskiej UE zaliczają wyeliminowanie intencjonalnych aktów dokonanych z pobudek rasistowskich. Realizację tego celu ma zapewnić zastosowanie środków prawnych oraz kształtujących świadomość i postawy. Celem pośrednim polityki antyrasistowskiej UE jest też eliminacja nieintencjonalnych praktyk rasistowskich, stanowiących istotę rasizmu instytucjonalnego/ strukturalnego. Prócz tego, polityka antyrasistowska ma na celu wpojenie szacunku dla innych ludzi i ich praw, ukształtowanie postawy nieużywania przemocy, tolerancji i szacunku dla różnorodności oraz przekonania do otwarcia się na inne kultury i dialogu z nimi (EC, 2001; CEU, 2001a; EP, 2006b). W przypadku eliminacji nieintencjonalnych praktyk oraz ukształtowania wymienionych przekonań i postaw najbardziej odpowiednie są środki kształtujące świadomość i postawy oraz środki pomagające formułować efektywną politykę antyrasistowską w różnych dziedzinach życia, choć w przypadku dyskryminacji pośredniej przewidziano również środki prawne. Ponadto, do kategorii celów pośrednich należy zaliczyć zapewnienie grupom doświadczającym lub zagrożonym rasizmem dostępu do edukacji, mieszkalnictwa, ochrony zdrowia, zatrudnienia, usług społecznych, systemu sprawiedliwości, politycznej partycypacji i reprezentacji, a także polepszenie (w sensie substancjalnym) sytuacji tych grup we wspomnianych obszarach (CEU, 2000; EC, 2001; EC, 2011). Cel ten może być osiągnięty za pomocą prowadzonych w tych obszarach polityk, skupionych specjalnie na potrzebach grup doświadczających/zagrożonych rasizmem.

Wyeliminowanie intencjonalnych aktów rasistowskich i nieintencjonalnych praktyk rasistowskich, a także ukształtowanie postaw szacunku, tolerancji i dialogu ma w zamierzeniu unijnych decydentów umożliwić swobodne cieszenie się przysługującymi prawami (CEU, 2008). Jednostki narażone na rasizm lub go doświadczające będą mogły korzystać z podstawowych praw i wolności, a także z praw przyznanych im z racji należenia do mniejszości etnicznych, językowych, religijnych itp. (EC, 2001). Spośród praw podstawowych warto wymienić, mocno akcentowane w dokumentach UE jako prawo człowieka, uprawnienie do bycia wolnym od dyskryminacji z powodu pochodzenia rasowego i etnicznego (CEU, 2000). Sytuacja, w której każdy tak samo może korzystać z przysługujących mu praw doprowadzi z kolei do osiągnięcia w społeczeństwie stanu formalnej równości. Co więcej, owa możliwość korzystania z praw będzie oznaczać, że mamy do czynienia ze społeczeństwem inkluzywnym, zintegrowanym, spójnym, pluralistycznym, sprawiedliwym, stabilnym, odpornym na 
radykalizację, pokojowym (CEU 2001a; EC, 2002; EP, 2004: EP, 2005c; EP, 2007b; EC, 2019; EP, 2019d; EC, 2020c).

Natomiast realizacja celu pośredniego, jakim jest zapewnienie zagrożonym grupom dostępu do edukacji, mieszkalnictwa, ochrony zdrowia, zatrudnienia, usług społecznych, systemu sprawiedliwości, politycznej partycypacji i reprezentacji, a także polepszenie sytuacji tych grup we wspomnianych obszarach, prowadzi do wyeliminowania nierówności. W ten sposób powstanie społeczeństwo, w którym zostanie urzeczywistniona równość o charakterze substancjalnym (tj. równość szans i równość rezultatów) oraz sprawiedliwość. To z kolei będzie skutkować społeczną inkluzją wspomnianych grup i ich integracją ze społeczeństwem (EC, 2001; EP, 2004; EP, 2005c; EP, 2010b; EC, 2011).

Autorzy badanych dokumentów dla opisania wizji pożądanej sytuacji, do której ma doprowadzić zaprojektowana przez nich polityka najczęściej posługiwali się następującymi pojęciami: prawa (człowieka, podstawowe), równość, inkluzja, dostęp. Co ciekawe, stosunkowo rzadko pojawia się pojęcie sprawiedliwości. Zaprezentowane powyżej ujęcie celów polityki antydyskryminacyjnej UE pozostaje w zakresie głównych swych wyznaczników stabilne przez cały badany okres. Można jedynie odnotować niewielki wzrost częstotliwości pojawiania się pojęcia spójności (od 2011 r.), inkluzji/ inkulzywności (od 2020 r.) oraz różnorodności (od 2020 r.). Wzrosty te są nieznaczne i nie przyczyniają się do zmiany ogólnej wizji pożądanej sytuacji, do której ma zmierzać badana polityka.

\section{Zmiany w zakresie struktury i organizacji polityki}

Na początku badanego okresu za działania mające na celu zwalczenie rasizmu, a ściślej rzecz ujmując, dyskryminacji rasowej, odpowiedzialna była w ramach KE Dyrekcja Generalna ds. Zatrudnienia, Spraw Społecznych i Równości Szans. W jej strukturze istniała jednostka ds. prawa pracy, podstawowych praw społecznych i antydyskryminacji, której powierzono kwestię zwalczania dyskryminacji ze względu na pochodzenie rasowe i etniczne, wiek, niepełnosprawność, religię lub przekonania oraz orientację seksualną (Bell, 2008, s. 79). W 2004 r. wewnątrz Komisji Europejskiej powołano złożoną z przedstawicieli wielu jej służb grupę, której zadaniem miało być koordynowanie inicjatyw odnoszących się do społeczności romskiej podejmowanych przez czternaście dyrekcji generalnych (Bell, 2008, s. 76). Od początku 2011 r. głównym podmiotem odpowiedzialnym w ramach KE za walkę z rasizmem stała się Dyrekcja Generalna ds. Sprawiedliwości i Konsumentów. W jej strukturze zadanie to powierzono jednostce ds. koordynacji inicjatyw dotyczących Romów i niedyskryminacji oraz jednostce ds. polityki praw podstawowych. Dyrekcja generalna, która poprzednio była odpowiedzialna za zwalczanie rasizmu, nosząca obecnie nazwę DG ds. Zatrudnienia, Spraw Społecznych i Włączenia Społecznego, też podejmuje inicjatywy na rzecz zwalczenia rasizmu, choć już tylko w obszarze zatrudnienia i spraw społecznych (Ruzza, 2013, s. 43).

KE w zwalczaniu rasizmu współpracuje z agencjami UE. Początkowo współpracowała z Europejskim Centrum Monitorowania Rasizmu i Ksenofobii. Z powodu oskar- 
żeń Centrum o zbyt wolne działanie i niewypełnianie swojej misji zostało ono rozwiązane, a od 2007 r. zaczęła funkcjonować powołana w jego miejsce Agencja Praw Podstawowych UE, która ma szerzej określone cele niż tylko zwalczanie rasizmu.

W 2015 r. KE utworzyła dwa nowe stanowiska: koordynatora ds. zwalczania nienawiści wobec muzułmanów oraz koordynatora ds. zwalczania antysemityzmu. W 2019 r. KE utworzyła w ramach swojej struktury Grupę Roboczą ds. Zwalczania Antysemityzmu, której zadaniem jest pomoc państwom członkowskim w implementacji Deklaracji Rady ws. Walki Przeciw Antysemityzmowi przyjętej w 2018 r.

Widoczna jest zmiana polegająca na wzroście liczby zewnętrznych struktur, które wzmacniają możliwości KE w zakresie analizy prawnej i prowadzonych polityk (Bell, 2008, s. 79). Od 2007 r. KE współpracuje z Equinet, czyli niezależną siecią organów równościowych istniejących w państwach członkowskich. W 2015 r. KE zastąpiła grupę rządowych ekspertów Grupą Wysokiego Szczebla ds. Niedyskryminacji, Równości i Różnorodności złożoną z ekspertów pochodzących z państw członkowskich, ale niebędących przedstawicielami rządów. W połowie 2016 r. KE powołała Grupę Wysokiego Szczebla ds. Zwalczania Rasizmu, Ksenofobii i Innych Form Nietolerancji. Stanowi ona platformę wspierającą wysiłki UE i państw członkowskich w zakresie efektywnej implementacji stosownych reguł oraz ukształtowania efektywnych polityk zapobiegających i zwalczających przestępstwa z nienawiści oraz mowę nienawiści. Te cele są realizowane poprzez dyskusje na temat deficytów, wyzwań i możliwych odpowiedzi na nie, wymianę dobrych praktyk, rozwijanie poradnictwa, wzmacnianie kooperacji i synergii między kluczowymi interesariuszami. Ponadto KE współpracuje $\mathrm{z}$ wieloma podmiotami społeczeństwa obywatelskiego, w tym sieciami ekspertów i transnarodowymi ruchami antyrasistowskimi (Fella, Ruzza, 2013). Natomiast w strukturze PE i RUE nie odnotowano zmiany, która byłaby istotna z punktu widzenia walki z rasizmem.

Polityka antyrasistowska UE prowadzona jest na dwa sposoby. Z jednej strony w oparciu o model praw człowieka, zgodnie z którym cele polityki są ściśle określone, środki mają głównie charakter prawny, łatwo można stwierdzić, czy cele są zgodne $\mathrm{z}$ istniejącymi ramami prawnymi (dużą rolę odgrywają $\mathrm{w}$ tym zakresie oddolnie powstające organizacje obywatelskie), sądy dokonują interpretacji prawa, zaś sankcje mają formalny charakter. Z drugiej strony polityka antyrasistowska UE prowadzona jest zgodnie z modelem tzw. nowego zarządzania (new governance), który opiera się na elastycznie określonych celach, ciągłym ich wypełnianiu treścią uwarunkowanym okolicznościami, nie-hierarchicznej strukturze, ale partnerskich relacjach pomiędzy podmiotami uczestniczącymi, odpowiedzialności motywowanej utrzymaniem reputacji, jeszcze mocniejszym niż w poprzednim modelu podkreślaniu oddolnego zaangażowania społecznych aktorów/interesariuszy w ustanawianiu norm i ich odpowiedzialności we wdrażaniu przez nieustające aktywności i praktyki (de Búrca, 2006, s. 3-4; Eberlein, Kerwer, 2004, s. 124-125). Pierwszy ze sposobów jest stale obecny, o czym świadczy kilka wiążących aktów prawnych (Dyrektywa Rasowa, Decyzja Ramowa 2008/913/JHA), stosowanie procedury naruszeniowej oraz wyroki TSUE. Jednak, jak wydaje się, większego znaczenia, zwłaszcza po wprowadzeniu kwestii romskiej w 2007 r. na agendę, nabrał drugi sposób, o czym może świadczyć rosnąca liczba planów działania i programów (np. program zwalczania dyskryminacji 
z 2000 r., strategia dotycząca Romów z 2011, 2012 i 2020 r., plan działania dotyczący integracji osób z krajów trzecich z 2016 r., plan działania na rzecz integracji i inkluzji z 2020 r., plan działania dotyczący zwalczania rasizmu z 2020 r.), wprowadzenie strategii mainstreaming, intensyfikacja współpracy z podmiotami ze sfery społeczeństwa obywatelskiego i wzmacnianie ich możliwości poprzez fundusze UE.

\section{Dyskusja nad rezultatami analizy}

Chociaż w dokumentach UE można stwierdzić obecność różnych koncepcji rasi$\mathrm{zmu}$, to $\mathrm{w}$ świetle przeprowadzonych badań, a więc na poziomie dyskursu koordynacyjnego między głównymi instytucjami UE, nie znajduje potwierdzenia teza Tomasza G. Grossego, że w ostatnich latach mamy w UE do czynienia z propagowaniem krytycznej teorii rasy (Grosse, 2021, s. A9). Choć teoria ta dzieli z koncepcją rasizmu instytucjonalnego przekonanie o nieintencjonalnych czynnikach dyskryminujących praktyk, to jednak jej rdzeniem są stosunki władzy w społeczeństwie. Przedstawia ona wizję społeczeństwa, w którym biała większość dominuje nad innymi grupami i cały system społeczny zorientowany jest na jej cele i interesy (Drozdowicz, 2012, s. 71). W badanych dokumentach nie odnaleziono fragmentów, za którymi kryłyby się założenia krytycznej teorii rasy. Jak wydaje się, dalekie echo tej teorii pobrzmiewa jedynie w unijnym planie działania przeciwko rasizmowi na lata 2020-2025 w miejscu, w którym stwierdza się, że rasizm może ujawniać się w sposobie, w jaki następuje dystrybucja władzy w społeczeństwie (EC, 2020a).

Wyniki przeprowadzonych badań potwierdzają tezę Marka Bella, że zmiana polityki antyrasistowskiej UE polega m.in. na dostrzeżeniu różnic pomiędzy grupami, które doświadczają rasizmu czy są nim zagrożone, a w konsekwencji na różnicowaniu koncepcji rasizmu (Bell, 2008, s. 75). Warto jednak zauważyć, że jedna z grup, a mianowicie Romowie, zwracają zdecydowanie większą uwagę decydentów UE niż inne grupy. Od 2015 roku widoczna jest próba równoważenia tej asymetrii w postaci kładzenia większego nacisku na zwalczanie rasizmu wobec osób o czarnym kolorze skóry, antysemityzmu i nienawiści wobec muzułmanów. Dostrzeżono również zróżnicowanie w sposobie doświadczania rasizmu, o czym świadczy nie tylko wyliczanie w dokumentach różnych form rasizmu, ale też zwrócenie większej uwagi na dyskryminację rasową o charakterze międzysegmentowym (intersectional discrimination).

Wzrost liczby kategorii osób dotkniętych rasizmem współgra z „duchem czasu”, który można określić zapożyczonym z prac Bradleya Campbella i Jasona Manninga terminem „powstanie kultury ofiar” (Campbell, Manning, 2018). Wcześniej dominowała kultura honoru, która nakazywała zmazać każdą zniewagę. Natomiast w sytuacji upowszechnienia się kultury ofiar ludzie odznaczają się niezwykłą wrażliwością na wszelkie przejawy naruszania ich godności, zaś pokrzywdzeni zyskują szczególną troskę i szacunek.

Analiza dokumentów ujawnia, że ich twórcy dostrzegają zmianę polegającą na wzroście znaczenia rasizmu ekspresywnego (expressive racism), a mniejszym znaczeniu rasizmu fizycznego. Takie rozróżnienie spotykamy w pracach Erika Bleicha, który pierwszym z wymienionych terminów określa zdarzenia komunikacyjne (językowe), 
zaś drugim akty fizyczne o charakterze rasistowskim (Bleich, 2003, s. 181). Przywiązywanie dużej wagi do wspomnianej formy rasizmu może świadczyć o przyjęciu koncepcji sprawiedliwości wyrównawczej, w której uprawniona jest ochrona przed zagrożeniem ze strony rasizmu ekspresywnego kosztem ograniczenia wolności słowa potencjalnych sprawców (The threat).

Sposób konceptualizacji problemu pokazuje kontekstualność zmian polityki antyrasistowskiej UE. Badania potwierdzają tezę Terri Givens i Rhondy Evans Case, że kontekst kolonializmu, faszyzmu i drugiej wojny światowej (zwłaszcza holokaustu) traci swoje znaczenie dla sposobu konceptualizowania walki z rasizmem, a zasadniczą rolę odgrywają procesy migracyjne i inne przyczyniające się do zróżnicowania (etnicznego, kulturowego, religijnego, językowego) społeczeństw (Givens, Evans Case, 2014). Tezę wspomnianych badaczek należy uzupełnić konstatacją, że w ostatnich latach kontekstem ważnym dla sposobu konceptualizowania polityki rasistowskiej stało się pojawienie się ruchów, polityków i partii politycznych, których retoryka i praktyka mają bliski związek z rasizmem. Warto zauważyć, że manifestacja rasizmu w ich wykonaniu może stanowić sposób na kontestację istniejących autorytetów, czego nie odnotowali autorzy badanych dokumentów.

Carolin Müller sformułowała tezę, że polityka antyrasistowska UE w swoich podstawach charakteryzuje się stabilnością, ponieważ nie zmierza do zmiany społecznych hierarchii czy też usunięcia podstaw, które reprodukują/tworzą system opresji (Müller, 2021, s. 7-8). Polityka antyrasistowska UE rzeczywiście nie jest aż tak radykalna w swoich celach. Wydaje się, że preferuje zmiany ewolucyjne, których rezultatów należy oczekiwać w długim okresie. Co prawda, wśród proponowanych środków można znaleźć takie, które mogły by spowodować znaczące zmiany: tzw. działania pozytywne, systemy kwotowe, zaangażowanie marginalizowanych grup w proces decyzyjny. Jednak działania pozytywne, jakie zaproponowano z pewnością nie przyczynią się do zmian postulowanych przez Müller, natomiast systemy kwotowe określane są w dokumentach UE jako środki wyjątkowe, zaś polityczne wzmocnienie grup doświadczających rasizmu jest bardzo rzadko w nich wspominane i w sposób mało konkretny. Co więcej, należy zgodzić się z Müller, że praktyka polegająca na współpracy KE z podmiotami społecznymi, które KE zasila funduszami, z pewnością nie umożliwi usłyszenia głosu podmiotów chcących zachwiać istniejącym porządkiem społecznym.

\section{Wnioski}

Celem artykułu było wykazanie, że polityka antyrasistowska UE w latach 20002020 ulegała zmianie, a następnie zaprezentowanie, na czym owe zmiany polegały i jaki charakter miały one oraz ich sekwencja. Uzyskane rezultaty badań pokazują, że główne zmiany polegały na bardziej zniuansowanym podejściu do walki z rasizmem: dostrzeżeniu różnych grup dotkniętych rasizmem, różnych sposobów doświadczania rasizmu, nowych odmian rasizmu (ekspresywnego, środowiskowego), nowych jego źródeł (politycy i partie polityczne, sztuczna inteligencja). Spośród zmian dotyczących proponowanych środków należy wymienić kładzenie większego nacisku na środki zapewniające równość substancjalną. Odnotować też trzeba wzmocnienie 
ochrony ofiar rasizmu. Ponadto, nastąpiło zwiększenie liczby jednostek w ramach KE odpowiedzialnych za walkę z rasizmem, a także wzrost liczby zewnętrznych struktur, które wzmacniają możliwości KE w zakresie analizy prawnej i prowadzonych polityk. Odnośnie do sposobu prowadzenia polityki antyrasistowskiej zauważalne jest zwiększenie znaczenia tzw. nowego sposobu zarządzania. Zmiany następowały wraz ze zmianą kontekstu społecznego i politycznego, w którym polityka antyrasistowska była tworzona. Zaobserwowane zmiany nie były radykalne, lecz następowały stopniowo. Miały charakter linearny, tzn. nie oznaczały zerwania z przeszłością. Polegały na przesunięciu akcentów oraz dołożeniu kolejnego elementu, a nie ich wymianie. W związku z tym rozwój polityki antyrasistowskiej UE można scharakteryzować jako szereg działań, które nie konkurują ze sobą, ale się uzupełniają, aby zrealizować określony z góry cel (zwalczenie rasizmu).

\section{Bibliografia}

Bell M. (2008), Racism and Equality in the European Union, Oxford University Press, Oxford-New York.

Bleich E. (2003), Race Politics in Britain and France - Ideas and Policymaking Since the 1960s, Cambridge University Press, Cambridge.

Campbell B., Manning J. (2018), The Rise of Victimhood Culture. Microaggressions, Safe Spaces, and the New Culture Wars, Palgrave Macmillan, Basingstoke, Hampshire-New York.

Carson M., Burns T. R., Calvo D. (2009), Paradigms in Public Policy. Theory and Practice of Paradigm Shifts in the EU, Peter Lang, Frankfurt am Main-Berlin-Bern-Bruxelles-New YorkOxford-Wien.

CEU (2000), Council Directive 2000/43/EC of 29 June 2000 implementing the principle of equal treatment between persons irrespective of racial or ethnic origin, OJ L 180, 19.07.2000, s. 22-26.

CEU (2001a), Declaration by the Council and the Representatives of the Governments of the Member States, meeting within the Council of 28 June 2001 on combating racism and xenophobia on the Internet by intensifying work with young people, OJ C 196, 12.07.2001, s. 1.

CEU (2001b), Council Conclusions on the World Conference against Racism, Racial Discrimination, Xenophobia and Related Intolerance, 16-17.07.2001, 10674/1/01 REV 1.

CEU (2002), Council conclusions on combating racism, antisemitism and xenophobia, 2526.04.2002, 8136/3/02 REV 3.

CEU (2007), Council Regulations No 168/2007 of 15 February 2007 establishing a European Union Agency for Fundamental Rights, 15.02.2007, OJ L 53, 22.02.2007, s. 1-14.

CEU (2008), Council Framework Decision 2008/913/JHA of 28 November 2008 on combating certain forms and expressions of racism and xenophobia by means of criminal law, 28.11.2008, OJ L 328, 6.12.2008, s. 55-58.

CEU (2015a), Combating racism - state of play of work in the Council, 02.06.2015, 9499/15.

CEU (2015b), External dimension of the fight against racism and xenophobia, 01.10.2015, 9512/1/15, REV 1 .

CEU (2018), Council Declaration on the fight against antisemitism and the development of a common security approach to better protect Jewish communities and institutions in Europe, 06.12.2018, 15213/18.

CEU (2020), Council Declaration on mainstreaming the fight against antisemitism across policyareas, $02.12 .2020,13637 / 20$. 
de Búrca G. (2006), EU Race Discrimination Law: a Hybrid Model?, http://www.eu-newgov.org/ database/DELIV/DLTFIaD03f_EU_Race_Discrimination_Law.pdf, 25.07.2021.

Drozdowicz J. (2012), Krytyczna teoria rasy (Critical Race Theory) i obecność koncepcji rasy w kontekście przeszłych i bieżacych amerykańskich dyskusji edukacyjnych, „Kultura-Społeczeństwo - Edukacja", nr 1.

Eberlein B., Kerwer D. (2004), New Governance in the European Union: A Theoretical Perspective, "Journal of Common Market Studies", vol. 42, nr 1.

EC (2001), Communication from the Commission contribution to the World Conference against Racism, Racial Discrimination, Xenophobia and Related Intolerance, 01.06.2001, COM(2001) 291 final.

EC (2002), Commission Staff Working Document: Legal reasoning for not referring to the concept of "public incitement to discrimination" in the Commission's proposal for a Council Framework Decision on combating racism and xenophobia, 03.04.2002, SEC(2002) 375.

EC (2003), Communication from the Commission to the European Parliament, the Council, the European Economic and Social Committee and the Committee of the Regions on the Activities of the European Monitoring Centre on Racism and Xenophobia, together with proposals to recast Council Regulation (EC) 1035/97, 05.08.2003, COM(2003) 483 final.

EC (2006), Report from the Commission to the European Parliament: The application of Directive 2000/43/EC of 29 June 2000 implementing the principle of equal treatment between persons irrespective of racial or ethnic origin, 15.12.2006, COM(2006) 643 final/2.

EC (2010), Report from the Commission to the European Parliament and the Council: The memory of the crimes committed by totalitarian regimes in Europe, 22.12.2010, COM(2010) 783 final.

EC (2011), Communication from the Commission to the European Parliament, the Council, the European Economic and Social Committee and the Committee of the Regions: An EU Framework for National Roma Integration Strategies up to 2020, 05.04.2011, COM(2011) 173 final.

EC (2012), Communication from the Commission to the European Parliament, the Council, the European Economic and Social Committee and the Committee of the Regions: National Roma Integration Strategies: a first step in the implementation of the EU Framework, 21.05.2012, COM(2012) 226 final.

EC (2014a), Report from the Commission to the European Parliament and the Council: Joint Report on the application of Council Directive 2000/43/EC of 29 June 2000 implementing the principle of equal treatment between persons irrespective of racial or ethnic origin ('Racial Equality Directive') and of Council Directive 2000/78/EC of 27 November 2000 establishing a general framework for equal treatment in employment and occupation ('Employment Equality Directive'), 17.01.2014, COM(2014) 2 final.

EC (2014b), Report from the Commission to the European Parliament and the Council on the implementation of Council Framework Decision 2008/913/JHA on combating certain forms and expressions of racism and xenophobia by means of criminal law, 27.01.2014, COM(2014) 27 final.

EC (2016a), The Code of Conduct on Countering Illegal Hate Speech Online, 31.05.2016, European Commission, https://ec.europa.eu/commission/presscorner/detail/en/IP_16_1937, 14.05.2021.

EC (2016b), Communication from the Commission to the European Parliament, the Council, the European Economic and Social Committee and the Committee of the Regions: Action Plan on the integration of third country nationals, 07.06.2016, COM(2016) 377 final.

EC (2019), Commission Staff Working Document: Countering racism and xenophobia in the EU: fostering a society where pluralism, tolerance and non-discrimination prevail, 15.03.2019, SWD(2019) 110 final. 
EC (2020a), Communication from the Commission to the European Parliament, the Council, the European Economic and Social Committee and the Committee of the Regions: A Union of equality: EU anti-racism action plan 2020-2025, 18.09.2020, COM(2020) 565 final.

EC (2020b), Communication from the Commission to the European Parliament and the Council: A Union of Equality: EU Roma strategic framework for equality, inclusion and participation, 07.10.2020, COM(2020) 620 final.

EC (2020c), Commission Staff Working Document. Analytical document accompanying the Communication from the Commission to the European Parliament and the Council. A Union of Equality: EU Roma strategic framework for equality, inclusion and participation and its accompanying proposal for a revised Council recommendation on national Roma strategic frameworks for equality, inclusion and participation, 07.10.2020, SWD(2020) 530 final.

EC (2020d), Communication from the Commission to the European Parliament, the Council, the European Economic and Social Committee and the Committee of the Regions: Action plan on Integration and Inclusion 2021-2027, 24.11.2020, COM(2020) 758 final.

EP (2000), European Parliament resolution on the European Union's position at the World Conference Against Racism and the current situation in the Union, 21.09.2000, OJ C 146, 17.05.2001, s. 110-113.

EP (2001a), European Parliament recommendation on the European Union's position at the World conference against racism, racial discrimination, xenophobia and related intolerance, 16.05.2001, OJ C 34 E, 7.02.2002, s. 208-210.

EP (2001b), European Parliament resolution on the situation as regards fundamental rights in the European Union, 05.07.2001, OJ C 65 E, 14.03.2002, s. 350-363.

EP (2001c), European Parliament resolution on the World Conference against Racism in Durban, 03.10.2001, OJ C 87 E, 11.04.2002, s. 149-151.

EP (2004), European Parliament resolution on the situation of women from minority groups in the European Union, 09.03.2004, OJ C 102 E, 28.04.2004, s. 497-503.

EP (2005a), European Parliament resolution on remembrance of the Holocaust, anti-semitism and racism, 27.01.2005, OJ C 253 e, 13.10.2005, s. 37-39.

EP (2005b), European Parliament resolution on the protection of minorities and anti-discrimination policies in an enlarged Europe, 08.06.2005, OJ 124 E, 25.05.2006, s. 405-415.

EP (2005c), European Parliament resolution on the situation of the Roma in the European Union, 28.04.2005, OJ C 45 E, 23.02.2006, s. 129-133.

EP (2006a), Declaration of the European Parliament on tackling racism in football, 14.03.2006, OJ C 291 E, 30.11.2006, s. 143-145.

EP (2006b), European Parliament resolution on non-discrimination and equal opportunities for all - a framework strategy, 14.06.2006, OJ C 300 E, 9.12.2006, s. 259-265.

EU (2007a), European Parliament recommendation to the Council of 21 June 2007 concerning the progress of the negotiations on the framework decision on action to combat racism and xenophobia, 21.06.2007 (2007/2067(INI)).

EP (2007b), European Parliament resolution of 27 September 2007 on the application of Council Directive 2000/43/EC of 29 June 2000 implementing the principle of equal treatment between persons irrespective of racial or ethnic origin, 27.09.2007 (2007/2094(INI)).

EP (2007c), European Parliament resolution of 13 December 2007 on combating the rise of extremism in Europe, 13.12.2007, OJ C 323 E, 13.12.2007, s. 494-496.

EP (2009), European Parliament resolution of 14 January 2009 on the situation of fundamental rights in the European Union 2004-2008, 14.01.2009, OJ C 46 E, 24.02.2010, s. 48-69.

EP (2010a), European Parliament resolution of 25 March 2010 on the Second European Roma Summit, 25.03.2010, OJ C 4 E, 7.01.2011, s. 7-11. 
EP (2010b), European Parliament resolution of 9 September 2010 on the situation of Roma and on freedom of movement in the European Union, 09.09.2010, OJ C 308 E, 20.10.2011, s. 73-78.

EP (2011), European Parliament resolution of 9 March 2011 on the EU strategy on Roma inclusion, 09.03.2011, OJ C 199 E, 7.07.2012, s. 112-131.

EP (2012), European Parliament resolution of 12 December 2012 on the situation of fundamental rights in the European Union (2010-2011), 12.12.2012, OJ C 434, 23.12.2015, s. 64-86.

EP (2013a), European Parliament resolution of 14 March 2013 on strengthening the fight against racism, xenophobia and hate crime, 14.03.2013, OJ C 36, 29.01.2016, s. 81-84.

EP (2013b), European Parliament resolution of 12 December 2013 on the progress made in the implementation of the National Roma Integration Strategies, 12.12.2013, OJ C 468, 15.12.2016, s. $157-162$.

EP (2014), European Parliament resolution of 27 February 2014 on the situation of fundamental rights in the European Union, 27.02.2014, OJ C 285, 29.08.2017, s. 112-134.

EP (2015a), European Parliament resolution of 15 April 2015 on the occasion of International Roma Day - anti-Gypsyism in Europe and EU recognition of the memorial day of the Roma genocide during World War II, 15.04.2015, OJ C 328, 6.09.2016, s. 4-7.

EP (2015b), European Parliament resolution of 8 September 2015 on the situation of fundamental rights in the European Union (2013-2014), 08.09.2015, OJ C 316, 22.09.2017, s. 2-36.

EP (2015c), European Parliament resolution of 25 November 2015 on the prevention of radicalisation and recruitment of European citizens by terrorist organisations, 25.11.2015, OJ C 366, 27.10.2017, s. 101-116.

EP (2016), European Parliament resolution of 13 December 2016 on the situation of fundamental rights in the European Union in 2015, 13.12.2016, OJ C 238, 6.07.2018, s. 2-27.

EP (2017a), European Parliament resolution of 1 June 2017 on combating anti-Semitism, 01.06.2017, OJ C 307, 30.08.2018, s. 183-185.

EP (2017b), European Parliament resolution of 25 October 2017 on fundamental rights aspects in Roma integration in the EU: fighting anti-Gypsyism, 25.10.2017, OJ C 346, 27.09.2018, s. 171-183.

EP (2018a), European Parliament resolution of 25 October 2018 on the rise of neo-fascist violence in Europe, 25.10.2018, OJ C 345, 16.10.2020, s. 22-27.

EP (2018b), European Parliament resolution of 13 November 2018 on minimum standards for minorities in the EU, 13.11.2018, OJ C 363, 28.10.2020, s. 13-26.

EP (2019a), European Parliament resolution of 16 January 2019 on the situation of fundamental rights in the European Union in 2017, 16.01.2019, OJ C 411, 27.11.2020, s. 94-106.

EP (2019b), European Parliament resolution of 12 February 2019 on the need for a strengthened post-2020 Strategic EU Framework for National Roma Inclusion Strategies and stepping up the fight against anti-Gypsyism, 12.02.2019, OJ C 449, 23.12.2020, s. 2-5.

EP (2019c), European Parliament resolution of 26 March 2019 on fundamental rights of people of African descent in Europe, 26.03.2019, OJ C 108, 26.03.2021, s. 2-7.

EP (2019d), European Parliament resolution of 19 September 2019 on the importance of European remembrance for the future of Europe, 19.09.2019, OJ C 171, 6.05.2021, s. 25-29.

EP (2020a), European Parliament resolution of 19 June 2020 on the anti-racism protests following the death of George Floyd, 19.06.2020, OJ C 362, 8.09.2021, s. 63-70.

EP (2020b), European Parliament resolution of 17 September 2020 on the implementation of National Roma Integration Strategies: combating negative attitudes towards people with Romani background in Europe, 17.09.2020, OJ C 385, 22.09.2021, s. 104-116.

EP (2020c), European Parliament resolution of 26 November 2020 on the situation of Fundamental Rights in the European Union-Annual Report for the years 2018-2019, 26.11.2020, OJ C $425,20.10 .2021$, s. 107-125. 
Fella S., Ruzza C. (red.) (2013), Anti-Racist Movements in the EU. Between Europeanisation and National Trajectories, Palgrave Macmillan, Basingstoke-Hampshire-New York.

Givens T. E., Evans Case R. (2014), Legislating Equality. The Politics of Antidiscrimination Policy in Europe, Oxford University Press, Oxford.

Grosse T. G. (2021), Demontaż narodowych identyfikacji, ,Rzeczpospolita” z dnia 2.07.2021 r.

Müller C. (2021), Anti-Racism in Europe: An Intersectional Approach to the Discourse on Empowerment through the EU Anti-Racism Action Plan 2020-2025, "Social Sciences", vol. 137, nr 10.

Ruzza C. (2013), AntiRacism at the EU Level, w: Anti-Racist Movements in the EU. Between Europeanisation and National Trajectories, red. S. Fella, C. Ruzza, Palgrave Macmillan, Basingstoke-Hampshire-New York.

The threat from the illiberal left. Don't underestimate the danger the left-leaning identity politics, "The Economist" z dnia 4.09.2021, https://www.economist.com/leaders/2021/09/04/thethreat-from-the-illiberal-left, 1.10.2021.

\section{Streszczenie}

Celem artykułu było wykazanie, że polityka antyrasistowska UE w latach 2000-2020 uległa zmianie, a następnie zaprezentowanie, na czym owe zmiany polegały i jaki miały charakter. Materiał badawczy stanowiły 62 dokumenty głównych instytucji UE: Komisji, Rady, Parlamentu Europejskiego. Uzyskane rezultaty badań pokazują, że główne zmiany polegały na bardziej zniuansowanym podejściu do walki z rasizmem: dostrzeżeniu różnych grup dotkniętych rasizmem, różnych sposobów doświadczania rasizmu, nowych odmian rasizmu (ekspresywnego, środowiskowego), nowych jego źródeł (politycy i partie polityczne, sztuczna inteligencja). Spośród zmian dotyczących proponowanych środków należy wymienić kładzenie większego nacisku na środki zapewniające równość substancjalną. Odnotować też trzeba wzmocnienie ochrony ofiar rasizmu. Ponadto, nastąpiło zwiększenie liczby jednostek w ramach KE odpowiedzialnych za walkę z rasizmem, a także wzrost liczby zewnętrznych struktur, które wzmacniają możliwości KE w zakresie analizy prawnej i prowadzonych polityk. Odnośnie do sposobu prowadzenia polityki antyrasistowskiej zauważalne jest zwiększenie znaczenia tzw. nowego sposobu zarządzania. Zaobserwowane zmiany nie były radykalne, lecz następowały stopniowo. Miały charakter linearny, tzn. nie oznaczały zerwania z przeszłością. Polegały na przesunięciu akcentów oraz dołożeniu kolejnego elementu, a nie ich wymianie. W związku z tym rozwój polityki antyrasistowskiej UE można scharakteryzować jako szereg działań, które nie konkurują ze sobą, ale się uzupełniają, aby zrealizować określony z góry cel.

Słowa kluczowe: rasizm, dyskryminacja, Unia Europejska, polityka UE, zmiana polityki

\section{Changes in the EU anti-racism policy in the years 2000-2020}

\section{Summary}

The aim of the article was to show that the EU's anti-racism policy changed in the years 2000-2020, and then to present what these changes consisted of and what their nature was. The research material consisted of 62 documents of the main EU institutions: the Commission, the Council, and the European Parliament. The obtained research results show that the main changes consisted in a more nuanced approach to the fight against racism: noticing different groups 
affected by racism, different ways of experiencing racism, new types of racism (expressive, environmental), new sources (politicians and political parties, artificial intelligence). Among the changes to the proposed measures, one should mention the greater emphasis on measures ensuring substantive equality. It should also be noted that the protection of victims of racism has been strengthened. In addition, there has been an increase in the number of units within the European Commission responsible for combating racism, as well as an increase in the number of external structures that strengthen the capabilities of the European Commission in the field of legal analysis and policies. With regard to the manner of conducting anti-racist policy, the importance of the so-called a new governance. The observed changes were not radical but occurred gradually. They were linear, i.e. they did not signify a break with the past. They consisted in shifting the accents and adding another element, not replacing them. Accordingly, the development of the EU's anti-racist policy can be characterized as a series of activities that do not compete with each other, but complement each other in order to achieve a predetermined goal.

Key words: racism, discrimination, European Union, EU policy, change of policy 
